Alma Mater Studiorum - Università di Bologna DEPARTMENT OF ECONOMICS

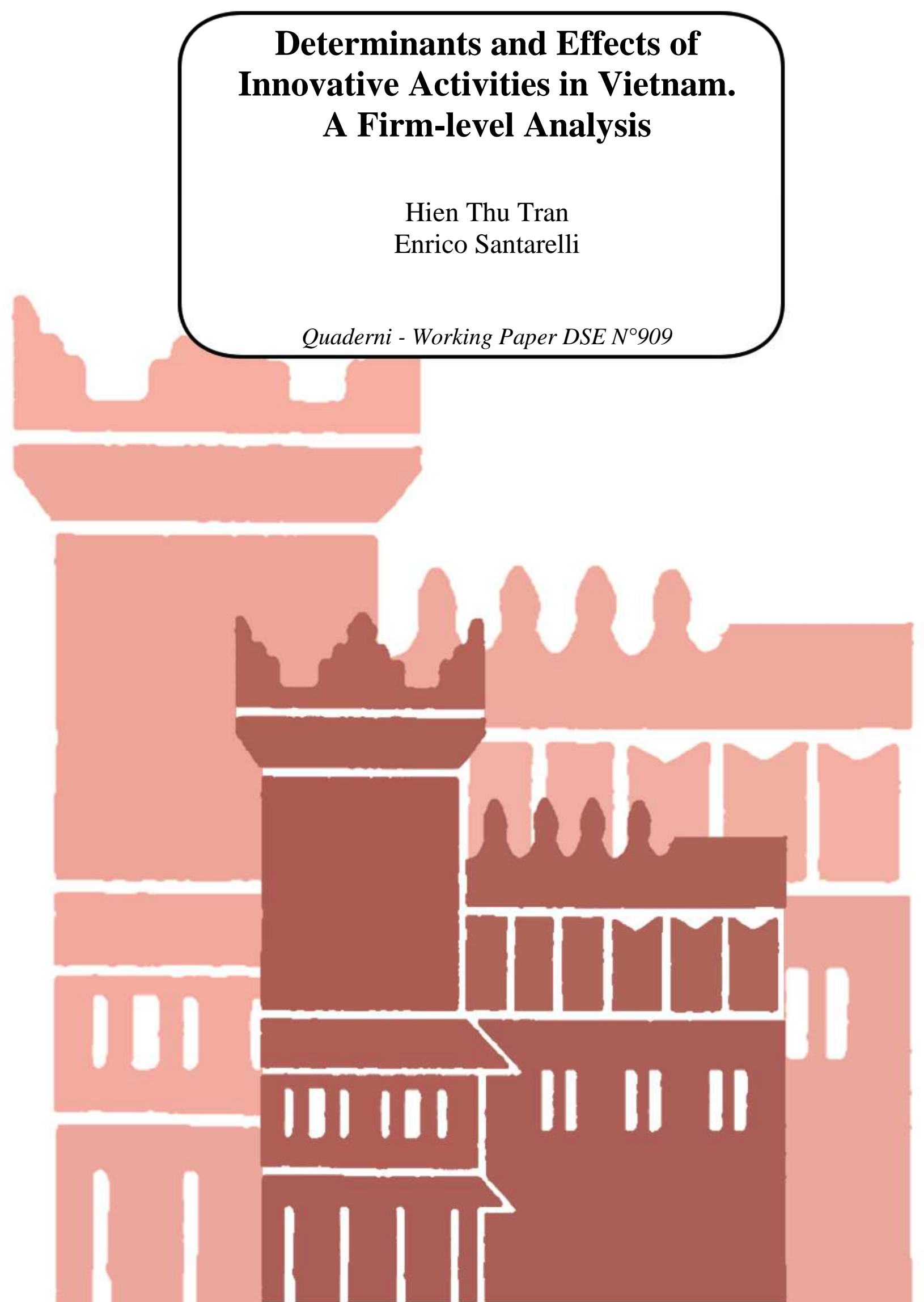




\title{
Determinants and Effects of Innovative Activities in Vietnam. A Firm-level Analysis
}

\author{
Hien Thu Tran \\ University of Bologna, Department of Economics Piazza Scaravilli, 2 - 40126 Bologna, Italy; \\ e-mail: thuhien.tran@unibo.it
}

\begin{abstract}
Enrico Santarelli
University of Bologna, Department of Economics; Piazza Scaravilli, 2 - 40126 Bologna, Italy; tel. +39 051 2098487; e-mail: enrico.santarelli@unibo.it
\end{abstract}

\begin{abstract}
:
This paper investigates the determinants of innovative activities and the innovation-performance relationship for the firm population in Vietnam in three consecutive stages: decision - investment - outcome. Cragg's two-tiered dynamic type-2 Tobit model and instrumental variable GMM method are applied to control for the selectivity and endogeneity of R\&D and innovation. After controlling for ownership types, industry and regional fixed-effects, key findings include: (i) R\&D and innovation activities not only stimulate firms' profitability and growth of sales, but also increase their survival propensity; (ii) private innovative firms significantly outperform their peers whereas the combination of young, small, and innovative characteristics in young innovative companies (YICs) does not bring the expected higher entrepreneurial performance as how it works in advanced countries; (iii) highly-leveraged firms, exporting firms, and diversified firms are more likely to be innovative than their counterparts, but the ability to transform innovative efforts into higher profitability and growth can only be witnessed among diversified firms; and (iv) firms being endowed with larger asset pool have more favorable conditions to engage in innovation activities, but do not necessarily produce superior performance relatively to their smaller counterparts. However, firm labor size is positively associated with both $\mathrm{R} \& \mathrm{D}$ intensity and entrepreneurial performance of firms. The dataset of population of existing firms (from 2000 to 2005) extracted from the annual enterprise survey conducted by Vietnam General Statistics Organization (GSO) is used for the empirical analysis.
\end{abstract}

Version: September 18, 2013

JEL Codes: O32; O33; O53; L25.

Keywords: R\&D; Innovation; YICs; Transition economies; Vietnam 


\section{Introduction}

Developing countries are still far lagged behind in both upstream production of fundamental research outputs and downstream conversion of research outputs into technological innovation, which further enlarges the gap with developed countries in terms of labor productivity, economic growth and profitability. While advanced countries call for policies supporting young, innovative companies who presumably allow reaping the fruit of breakthrough innovations as a source of economic growth, the developing world still plays around with policies aimed at improving its institutional infrastructure and financial system to fulfil the gap. Despite this policy concern, until now there has been a lack of studies which explicitly examine the importance of innovation and $R \& D$ in general as well as the possible contribution of young innovative companies in particular to the economic performance of developing / transition countries (Krammer, 2009).

During its transition to a market economy since its 1986 economic reform known as 'doimoi', Vietnam has become a fast growing economy, with an average annual GDP growth rate of over $7 \%$. Despite fast growth, the country is characterized by a substantial churning of firms, along with the reallocation of labor and resources across continuing firms. As this threatens the efficiency of the macro-economy, scholars and policy makers in recent years have increasingly paid significant attempts to leverage firm-level dynamics as well as the innovative contribution of new entrepreneurial ventures as a crucial engine for economic growth. We take Vietnam as an ideal laboratory for examining some crucial determinants and effects of innovative activities in a country that displays the features of both a developing and a transition economy. In this connection, objectives and main novelties of the present paper are three-fold.

First, investigate the firm-level innovation process in three interrelated and consecutive equations: $R \& D$ decision (what determines a firm to engage in $R \& D$ ?); $R \& D$ expenditure (once a firm decides to engage in $R \& D$, what determines the size of its investment?); and innovation outcome (how does a firm's R\&D intensity influence its profitability and growth?). Since they are interrelated, we consider the possibility that the unobservable disturbances of the three equations are correlated. Cragg's two-tiered dynamic type-2 Tobit model and Heckman's approximation for initial conditions method are adopted to control for the selection bias of firms engaging in $R \& D$ in the first two stages. The instrumental variable GMM and differenced GMM method are applied for both static and dynamic treatment of the third outcome stage. 
Second, study profitability and growth potential of young innovative companies (YICs) and private innovative companies (PICs) under the assumption that they will be more likely to engage in innovation activities, and hence perform better than other firms. The aim being to find evidences (not) justifying the commonly supported hypothesis in advanced countries that "YICs significantly outperform other counterparts" for the case of Vietnam.

Third, in controlling for potential survivor bias, explore the survival propensity of innovative firms. The dataset used for the empirical analysis of this paper is from the annual enterprise survey conducted by Vietnam General Statistics Organization (GSO), which covers the whole population of existing firms from 2000 to 2005 (nearly 400,000 observations). However, due to the high churning rate of firms and as we want to trace innovation activities and performance of firms overtime, we extract a balanced panel of 11006 non-agricultural firms established before 2000 and still active in 2005 for analysis of the first two objectives. For the third objective, the whole population of firms is used to control for the potential survival bias of innovative firms.

After controlling for ownership types, industry and regional fixed-effects, empirical evidences support our two hypotheses: (i) R\&D and innovation activities play an important role in stimulating firms' profitability and growth of sales; and (ii) private innovative firms significantly outperform their peers. Other worth-noting findings include: First, factors motivating firms to be involved in R\&D do not necessarily induce them to invest more in R\&D. For instance, loans have a leverage effect on R\&D engagement decision, but demotivate firms to spend more on R\&D. In the same fashion, a large pool of skilled technical employees on one hand stimulates firms to conduct R\&D activities, but on the other hand deters their R\&D investment. Similarly, although firms with some prior innovation output achievements are more likely to conduct R\&D activities, they do not necessarily invest more on R\&D compared to their counterparts. Firms exporting their products/services into international markets are more likely to be innovative but there is no evidence suggesting that they will spend more on R\&D. Second, multi-business firms are generally more $R \& D$ intensive and perform better than single-business firms do. Third, we find contradictory effect between labor size and economic size on firm-level entrepreneurial performance. Finally, although younger firms are more R\&D intensive and innovative, they do not produce equivalent outperformance. Therefore, the combination of young, small, and innovative characteristics in YICs does not bring the expected higher entrepreneurial performance as how it works in advanced countries. 
The paper is structured as follows. Section 2 summarizes the literature on the determinants of innovation and the innovation-performance relationship, as well as proposes research hypotheses. Section 3 describes the dataset and presents the operationalization of variables together with their descriptive statistics and correlation matrix. Section 4 develops the methodological approach(es) that we apply to obtain final empirical estimation. Section 5 discusses the estimation results. Section 6 controls for the potential survival bias in our estimation model; and finally, section 7 gives some concluding remarks.

\section{Literature review}

For decades, there has been a divergence in the focus of classical literature on determinants of innovation between the economics and the management discipline. On one hand, stimulated by Schumpeter's writings on the relationship among innovation, market structure, and industry characteristics, industrial organization economists have concentrated on the impacts of external or environmental factors to explain differences in firms' innovative activities (Cohen, 1995). In this respect, the most frequently studied sources of inter-industry variation in innovative strategy are: firm size and market structure (the Schumpeterian view); market size and growth in demand (Schmookler, 1996); industrial sectors (Rothwell, 1974); market competencies (Cooper, 1984); technological opportunity and the ability to appropriate returns from innovation activities (Cohen and Levin, 1989). Obviously, market structure, market growth and market size affect availability and abundance of entrepreneurial opportunities. Thus, rapidly growing industries assimilate and promote new innovations, whereas mature and declining ones give priority to economies of scale and scope. Unlike industrial organization economics, more behaviorally oriented economics, especially evolutionary economics, studies intra-industry differences in innovative strategies (Nelson and Winter, 1982). This analysis underlines the existence of significant differences among firms, not only in terms of size but also in terms of technological capabilities that may also explain differences in their innovation behaviors and performance (Dosi, 1988). From this perspective, innovative activities tend to be accumulated from learning, exhibited in tacit and firm-specific knowledge, and embodied in organizational routines. However, despite the consensus about the fundamental importance of industry-level conditions among industrial economists and significant attempts to incorporate firm-level technological capabilities of 
evolutionary economists, there has still been a lacuna of research on firm-level characteristics that distinguish innovative firms within industries (Cohen, 1995).

On the other hand, ignoring the macro-effect of industries and countries, the management literature focused on managerial and organizational indicators ${ }^{1}$. Since the 1960 s, organizational theorists have attempted to identify unique characteristics of highly innovative firms, but with rather inconsistent and inconclusive results. The "resource-based view of the firm" emphasizes the role of firms' resources and capabilities in R\&D activities (Canto and Gonzalez, 1999). Other organizational factors taken into account are types of innovation (Downs and Mohr, 1976); structural integration variables, goals and strategies (Miller and Friesen, 1984); perceptual criteria (risk-taking, pro-activeness, sense of achievement) (Souitaris, 2002); contextual factors (firm age, growth rate, profitability, earnings from export, competitive market) (Miller and Friesen, 1984); organizational and technical competencies (Rothwell, 1992); education of personnel (Miller and Friesen, 1984). However, the shortcoming of studies in this stream is the neglect of the moderating effects of industry-level conditions.

Several works have attempted to link the economic and the management literature in exploring the determinants of innovation (e.g. Souitaris, 2002; Romero and Roman, 2012). However, whichever literature stream that the contribution is based upon, all studied factors (either industry-level or firm-level) are typically correlated to the size and age attributes of firms.

While antecedents of innovation have been explored extensively and insightfully for decades, research on the consequences of innovation, or innovation as antecedent of firm performance, remains under-investigated and produces mixed results. At the macro level, it is widely agreed that innovation is the engine of economic growth and is considered as an important measure for growth and competitiveness of industries and countries (Dosi et al., 2007). At the micro level, controversial arguments still exist around the economic value of innovation. Various empirical studies report that innovation does not influence firm performance (e.g. Birley and Westhead, 1990; Heunks, 1998), or find negative performance implications of innovation (e.g. Vermeulen et al., 2005). Meanwhile, the majority of research report positive effects (e.g. DeCarolis and Deeds, 1999; Guo et al., 2006). As Freeman (1994: 81) notes, "the fastest growing firms are distinguished by their capacity for a flow of incremental innovations as well as outstanding success with a radical innovation”. Therefore, investigating the growth of firms, especially fast

\footnotetext{
${ }^{1}$ For a comprehensive review, see Souitaris (2002).
} 
growing ones, does not only shed light on their performance in the economy but also on the growth of the economy as a whole (Carree and Thurik, 2010). Innovation produces positive or negative effect, which is again significantly associated to the size and age of firms. In the following sections, we will review how innovation behaviors and entrepreneurial performance diverge with respect to the size and age attributes of firms embodied in start-ups versus incumbents, small firms versus large firms, and their combination in YICs.

\subsection{Start-ups versus incumbents}

According to Schumpeter (1934), innovation fosters economic growth through the mechanism of "creative destruction", which sees new and independent firms replacing old and unprofitable ones to expand existing markets or create entirely new markets through the commercialization of innovations (Audretsch, 1995). Therefore, while new ventures seem to be active in exploiting knowledge characterized by high uncertainty and high information asymmetries (Acs et al., 2009), large players locked into existing products and processes oversee promising opportunities (Santarelli and Tran, 2012). The fear of losing profits and current market share restricts incumbents' innovation incentives on incremental innovations rather than radical ones that have the potential to create new markets (Henderson, 1993) in order to preempt entry. Being less concerned with safeguarding their current assets, new entrepreneurial firms are hence more likely to introduce radical innovations and create new markets (Veugelers, 2008). They also represent a viable mechanism to transform academic knowledge into commercial innovation opportunities which are normally overseen by incumbents (Carree et al., 2013). Their involvement in innovation may indirectly stimulate incumbents' innovations depending on nature of innovations (radical versus incremental) (Henderson, 1993), strength of intellectual property protection (Anton and Yao, 1994), stage of industry life cycle (Klepper, 1996), effectiveness of the market for ideas, control over complementary assets, association with venture capital, likelihood of cooperation with incumbents (Gans et al., 2002).

\subsection{Small firms versus large firms}

Large literature dating back to Schumpeter (1942) has discussed whether large or small firms matter more for innovation. On one hand, economies of scale and scope in the R\&D process and complementarities with other competences needed to commercialize new products favor 
innovation of large-sized firms. In this line, several studies note, firstly, that larger firms operating in a concentrated market are the main engine of technological progress (Cohen and Levin, 1989); secondly, that they are more likely to undertake R\&D activity as they have scale and scope economies in the production of innovations and better access to finance; and thirdly, that firms with greater monopoly power have greater incentives to innovate because they can better appropriate returns from their R\&D investments (Blundell et al., 1999). On the other hand, decreasing returns to scale in the production of innovation due to loss of managerial control and the bureaucratization of innovation activities in large firms favor small-sized ones. Some authors have also highlighted the problems large firms face in attempting to innovate, such as inertia, myopia, and rigidities that may lead them to be risk averse and conservative in their innovative efforts (Levinthal and March, 1993). Therefore, for decades, the contribution of small and medium-sized enterprises (SMEs) to job creation, national innovation system, and regional economic growth has been found to be crucial (Acs and Audretsch, 1990; Audretsch, 2006). High-technology SMEs have a key role in developing and exploiting new technologies which contribute to the generation of new sectors and stir the future innovations (Vaona and Pianta, 2008). Small firms can benefit from advantages in implementing R\&D projects, because their managers often know more about technology besides exhibiting stronger entrepreneurial spirit and a positive attitude towards risk taking. Indeed, Rosenbusch et al. (2011) do a meta-analysis of the innovation performance relationship and find out that innovation has a positive effect on the performance of SMEs although innovation can imply high initial risks and uncertainty.

\subsection{Young innovative companies (YICs)}

It has been widely recognized that innovation serves to increase profitability and drive organic growth of small and start-up firms, for which it may be a matter of life or death (Cefis and Marsili, 2006). But only recently when scholars focused their attention to the complimentary effect of smallness and newness of innovative firms, has significant attention been paid to YICs in many developed countries; not because they are large in numbers and thus contribute substantially to employment or GDP, but rather from the expectations on their technological progress through $R \& D$ and innovation that shape new markets and promote economic growth. Public awareness of new technology-based firms (NTBFs) arose in the early 1980s, when several traditional industries were in decline and some fast-growing new industries began to emerge 
(Licht and Nerlinger, 1998). Despite conflicting arguments around the important role of NTBFs in the overall national economic performance, researchers still share one common consensus that their existence indeed stimulates technological change and productivity growth. According to Baumol et al. (2007), productivity growth in advanced economies over the last two decades has been due to the development of innovative entrepreneurial companies. Empirically, YICs have been proved to show a significantly higher innovative performance compared to other innovators or non-innovators in both developed countries such as Germany (Schneider and Veugelers, 2008), UK (Freel, 2000), Belgium (Czarnitzki and Delanote, 2013), and developing ones such as India (Kumar and Saqib, 1996), China (Hu et al., 2005), and Taiwan (Chuang and Lin, 1999).

\subsection{Hypotheses}

Policy makers and scholars in developing an dtransition countries are worried about the increasing gap with developed nations with respect to labor productivity, economic development / growth at macro-level and technological innovation at micro-level. Along with institutional reform and political stability, technological progress is seen as a critical ingredient for sustained economic growth and catch-up. Within the economies exhibiting substantial catch-up, many technologically weak firms learned to innovate by first imitating technologies created in developed economies. Over time they make a transition from imitation to innovation, including the creation of patentable knowledge (Hu et al., 2005). R\&D and technology transfer have both substitution and complementary relationship. On one hand, technology transfer should substitute for the firm's internal R\&D effort. On the other hand, technology transfer stimulates firms to improve their learning and absorptive capacity through R\&D to adapt new technology with their infrastructure (Cohen and Levinthal, 1989). A by-product of R\&D is therefore to enhance a firm's absorptive capacity, which in turn boosts the efficacy of technology transfer. Kim and Nelson (2000) suggest that imitation through the adoption of existing technologies serves as an effective learning experience that paves the way for indigenous technological innovation. Despite the unique pattern of innovation and R\&D activities in developing countries (from imitation to innovation), we still propose the following hypothesis:

\section{H1: R\&D investment stimulates the entrepreneurial performance of firms}


Developing and transition countries, including Vietnam, may be particularly dominated by gazelles that are solely defined on fast growth, and need not necessarily be small, young, and innovative-active. In fact, many gazelles in countries staying far from the technology frontier derive their fast growth from a broader set of competitive advantages (Holzl, 2009). Thus, it is not so obvious that although SMEs account for the majority of firm population in Vietnam, they also play a role similar to their counterparts in developed countries with respect to economic and innovative contribution. Given their high cost and time consuming nature, R\&D activities are unaffordable for the majority of SMEs in developing/transition countries. Even within the group of innovative SMEs, most of them have a low innovative profile, mainly acquiring, adapting, applying new technology to the firm. Only a minor fraction is involved in leading-edge high level research, leading to radical innovations. Together with poorly-functioned appropriation mechanisms, small firms actually expect to free ride on incumbents’ R\&D investments. Indeed, Santarelli and Tran (2012) find out that incumbents' growth generates positive knowledge spillovers, and hence, profitable opportunities for start-ups. Thus, while YICs attracted great attention from both academics and policy makers in advanced countries as engines of growth, job creation, and strong drivers of innovations, we want to understand whether the same story occurs in developing countries by creating a benchmark study for the case of Vietnam. In other words, can we confirm also for the case of Vietnam that YICs outperform their counterparts?

H2: Young innovative firms have superior entrepreneurial performance than their counterparts

It is also our assumption that young and small firms are normally at disadvantaged positions in developing countries. These countries, with their inherently poor business development services and ill institutional / financial supporting systems cannot create a level playing field for small and young firms who mainly focus on their survival as the priority. Innovation activities, therefore, are more popular among larger incumbents who have accumulated sufficient resources and experience for costly innovations. Together with the popular trend of privatizing and liquidating state-owned firms, Vietnam has recently witnessed the emergence of a dynamic private sector (Santarelli and Tran, 2012). Besides being an important source of new employment, important promoters of technological change and innovation, private firms are active in capturing entrepreneurial opportunities for their growth (Santarelli and Tran, 2013), and 
thus are expected to be more innovative and R\&D intensive. Instead of isolating smallness and newness of innovative firms, we want to take into account their private ownership type with the hypothesis that private innovative firms will have superior performance than their peers. The participation of private sector actors in innovation process has also been found to be preferable in European countries (Autio et al., 2007).

H3: Private innovative firms have superior entrepreneurial performance than their counterparts

\section{Data description and definition of variables}

The dataset used for this paper is the annual enterprise survey database conducted by Vietnam General Statistics Organization (GSO) from 2000 to 2005. It covers the whole population of existing firms in 6 years which is up to nearly 400,000 observations. The GSO survey is comprehensive and harmonized across provinces and industries to get a coherent view on various aspects of firms, including segment data (ISIC code, industry sales, size, and assets), accounting data (debts, revenue, profit, assets), basic demographic data (year of inception, ownership type, size of labor force) and innovation data ( $\&$ \& expenditure, innovation investment $^{2}$, technical personnel). However, due to the high churning rate of firms and as we want to trace the innovation activities and performance of firms overtime, we extract the balanced panel of 11006 non-agricultural firms establishing before 2000 and still existing until 2005 (66042 observations) for the empirical evidence of determinants of innovation and innovation-performance relationship. To control for the potential survival bias of innovative firms, the whole population of firms will be used.

Following is the list of variables we use in this paper:

Entrepreneurial performance: Geroski and Machin (1992) find relatively large and persistent differences in the profits of innovators and non-innovators. According to Freel (2000), small innovators may have slower growth in profits and lower levels of absolute profit than their less innovative counterparts; however, they are likely to enjoy higher average profit margins, which

\footnotetext{
${ }^{2}$ In this paper, innovation investment includes three components: (i) construction and assembly works; (ii) machinery and equipment; and (iii) technology renovation. It is therefore largely a measure of technological change embodied in intermediate and capital goods, which has been shown to be a major determinant of the overall innovation activity by SMEs (Kleinknecht, 1987; Santarelli and Sterlacchini, 1990).
} 
in turn are a measure of improved internal efficiency and value added. Due to the requirement to repay initial investments (sunk cost) or fund further investments, small innovators may not enjoy higher net profits. In this paper, we consider the effect of innovation on profit margins (the rate of return on sales) ${ }^{3}$. Return on sales (ROS) indicates how net income is earned from each thousand Vietnamese dong (VND) of sales. ROS is the ratio between after-tax profits and sales.

R\&D intensity / Innovation investment rate: R\&D intensity is measured as the proportion of $R \& D$ expenditures to business expenditures, whereas innovation investment rate is the ratio of investment into innovation activities over total annual investment of the firm. Both measures are expressed in decimal points and thus have values between 0 and 1 . We allow for a non-linear relationship by including their squared values in the regression. There are strong a priori reasons to expect endogeneity of R\&D and innovation variable (Veugelers, 1997). Firms that invest in $\mathrm{R} \& \mathrm{D}$ / innovation are likely to have a superior capacity to innovate. R\&D enables firms to develop new products/processes and external absorptive capacity to absorb knowledge from outside effectively (Cohen and Levinthal, 1990), leading to greater flexibility and adaptability.

Young innovative company (YIC): is a dummy indicating whether a firm is a YIC, according to the definition of the European Commission, as specified in article 35 of the General Block Exemption Regulation. By the European definition, these companies are less than 6 years old, have fewer than 250 employees, and are highly R\&D intensive (R\&D intensity $>15 \%$ ). Besides being small, young and intensively engaged in innovation activities, a firm is a YIC once it meets the criteria for the first time in the period under analysis. This allows investigating the growth of YICs overtime compared with other companies even if these YICs could exceed the size and age threshold of the YIC definition in following years (Czarnitzki and Delanote (2013).

Private innovative firms (PICs) / Small and young firms (SY): We add two dummies to analyze the influence of being a PIC and a SY on growth and profitability. Although a YIC is highly R\&D intensive, the only requirement we set for a PIC is to have R\&D spending above zero. SY companies are small and young, specified according to the YIC definition, but do not have any R\&D requirements. We check thus whether the size and age requirements significantly influence firm growth and profitability. Once a company is classified as a PIC or a SY, it stays at

\footnotetext{
${ }^{3}$ The rationales for using ROS rather than the widely-used logarithm of profit or ROA (return on assets) are: logarithm of profit excludes firms operating at loss (negative profit) from the analysis, and sales is generally expressed in current monetary terms whereas assets normally carry book values and require a longer time frame of availability (Geringer et al., 1989).
} 
that status for the rest of the sample period. In the regression analysis, we code these dummies as mutually exclusive variables to ease the comparison of performance among them.

Control variables: To isolate the relationship between R\&D / innovation investment and entrepreneurial performance, we have to control for other variables that are likely to affect profitability and sales growth of sampled firms.

- Firm size: The earliest contributions linking the size of the firm and its growth developed around the Law of Proportionate Effect (LPE), or Gibrat's (1931) Law, stating that a firm's growth rate is independent of its current size. In general, LPE was rejected in empirical studies, although some authors found that it does hold for larger firms in the economy, but not for smallest ones (Lotti et al., 2009). Some other studies find an inverse relationship between firm size and firm growth (Lotti et al., 2003). Characteristics like market concentration, technological opportunities, the stage of technology life cycle, all matter as intervening variables for the effect of firm size. Economic size is taken as the natural logarithm of total firm assets. Labor force size is measured as the natural logarithm of the total number of employees. Quadratic terms are also added to establish a non-linear relationship between firm size and its performance.

- Firm age: Empirical studies have shown that new/young firms are characterized by a relatively high risk of failure during the first years of their existence. The main reasons for such a "liability of newness" are the problems of setting an organizational structure and getting the new units to work efficiently enough to keep pace with their competitors (Fritsch et al., 2006). For older firms, the "liability of aging" could be the inflexibility of established organizations, erosion of technology, products, and business concepts over time. Age as a proxy for the level of experience, learning and managerial competencies that a firm accumulates overtime is considered as an important determinant of firm growth. In view of the dynamic features of an emerging market like Vietnam's, aging may impede the ability of firms to be alert and capture profit opportunities with timeliness and efficiency. The effect of firm age is explored by means of the number of years that the firm has been in continuous operation.

- Capital intensity: Some firms are, by the nature of technology, more capital-intensive than others. Within any particular industry, a firm may choose a highly automated process or a more labor-intensive one. In general, high capital intensity imposes a greater degree of risk because assets are frozen in long-lived forms which may not be easy to be sold, as well as hinders the setup and survival of new firms due to the relatively large amount of resources that is needed for 
attaining the minimum efficient size (Audretsch et al., 2000). Given that return (and risk) varies with capital intensity, differences in profitability are likely to be associated with differences in capital intensity between innovative and non-innovative firms. The present study uses the ratio of net fixed assets to total number of employees.

- Debt ratio: The finance literature indicates that the leverage situation of firms strongly influences their value. Opler and Titman (1994) found that highly leveraged firms lose a substantial market share to their more conservatively financed competitors. Empirical studies find a negative relationship between a firm's debt ratio and its $R \& D$ intensity. This may reflect the fact that those firms pursue less R\&D activities, because they have access to new external funds and at the same time have to serve existing debt (Czarnitzki and Kraft, 2004). Thus, the debt ratio, measured as the ratio of total debts to total assets, is adopted to isolate the effect of a firm's leverage capacity on its innovation activities and entrepreneurial performance.

- Technological resources: Firms with higher internal technological capacity / skills endowment might be better both at absorbing incoming spillovers and at protecting their knowledge through different appropriation mechanisms (Piva and Vivarelli, 2009). It has been widely recognized that technical resources may be measured through indicators of R\&D inputs, R\&D processes, R\&D outputs (Audretsch, 1995). In this study, the rate of qualified R\&D teams and technical employees in the total labor force of firms is adopted as a proxy for their technological resources. Indeed, skilled technical workers in comparison with their unskilled counterparts, are more suited to deal with complexity of innovation (Song et al., 2003), more likely to absorb knowledge and consequently reinforce the absorptive capacity of a given organization (Cohen and Levinthal, 1990), and more successful in exploiting innovative ideas.

- Innovation output: is measured by the number of innovative projects completed and registered at three levels: the enterprise, the ministries and the government. Given the poorlyfunctioned intellectual property rights system in Vietnam, patent-based measures of innovation might be unable to fully capture innovative efforts of firms. In addition, by focusing on patents rather than on commercialized products, prior research has tended to exclude service industries where obtaining patents is uncommon (Criscuolo et al., 2012). There are neither strong theoretical reasons nor strong empirical evidence suggesting that the appropriability mechanisms of innovations would have any robust effect upon the innovation process (Dosi et al., 2007). 
Another policy concern is that patenting can become a vehicle for impeding entry and the innovation that often accompanies it.

- Export: There should exist a positive relationship between value added, uniqueness of product and export propensity. Influential international trade models (Krugman, 1979) suggest that innovation is, indeed, the driving force behind export. Through innovation, innovating firms will obtain and sustain their competitive advantage domestically and internationally. In practice, however, the link is less established (see Castellani, 2002, for a survey). In this paper, “export” is a dummy indicating whether a firm is involved in exporting its products / services or not.

- Diversification: Diversified firms realize higher profit margin than firms with a highly concentrated products/process spectrum (Tran and Zaninotto, 2012). A further firm characteristic that has been shown to have a positive effect on the propensity of a firm to engage in R\&D is its degree of product diversification. A diversified firm can benefit from potential internal knowledge spillovers and so be better positioned to understand the applicability of new ideas (Tran and Zaninotto, 2012). "Diversification” is a dummy which attains 1 if the firm diversifies its production into another industry; and 0 otherwise.

- Foreign investment: Foreign direct investment (FDI) provides probably the most important and cheapest channel of direct technology transfer to developing countries. Foreign investment might also represent an important source of intra-industry spillovers to local firms without foreign participation. International trade works as a channel of technology transfer, either through imports of intermediate products and capital equipment or through learning-by-exporting into industrial countries (see Damijan et al., 2003). In this paper, the variable is constructed as the ratio of foreign investment to the total annual investment.

- Industry effects: Since we include observations across multiple industries, it comes essential to consider industry-level fixed effects. The effect of industry life-cycle is proxied by average firm size of each 2-digit industry. Large average firm size indicates the maturity of the industry; on the contrary, small average firm size suggests the availability of abundant profitable opportunities which attracts new and small entries, and indicates the growing stage of the industry. To measure industry-level performance this paper uses average ROS of all firms in the 2-digit industry as the proxy for industry profitability level.

- Province control: Regional factors play an important role and add significantly to the explanation of new business survival (Fritsch et al., 2006). According to North and Smallbone 
(1995), there is a strong correlation between local characteristics and firm growth. 64 province dummies are included to isolate unobserved heterogeneity across different Vietnamese provinces.

- Ownership type: Six dummies which stand for state-owned firms; partnership and cooperatives; private firms; limited liability firms; joint stock firms; and foreign invested firms are included in the analysis to isolate the impact of legal ownership type on firms' innovation activities and entrepreneurial performance.

Appendix 1 presents the construction and descriptive statistics of adopted variables. Appendix 2 lists the pair-wise correlation matrix of the dependent variable and independent variables.

\section{Estimation models}

\subsection{R\&D decision and expenditure}

Following Artes (2009: 120) we distinguish between long-run and short-run decisions of firms regarding R\&D: "Long-run or strategic decision is whether to conduct R\&D or not and the short run choice is how much to invest once the firm decides to be innovative". We assume that firms will be involved in $R \& D$ if the expected profits from conducting $R \& D$ activities are positive ( $>0)$. Let $\pi_{i t}^{*}$ be expected net profits of firm $i$ from conducting $\mathrm{R} \& \mathrm{D}$ in period $t$. The selection equation can be specified as follows:

$$
\begin{gathered}
R D_{i t}=\left\{\begin{array}{c}
1 \text { if } \pi_{i t}^{*}=\alpha_{1} R D_{i, t-1}+\alpha_{2} W_{i t}+c_{i 1}+\varepsilon_{i t 1}>0 \\
0 \text { if } \pi_{i t}^{*}=\alpha_{1} R D_{i, t-1}+\alpha_{2} W_{i t}+c_{i 1}+\varepsilon_{i t 1} \leq 0
\end{array}(1)\right. \\
(i=1,2, \ldots, n ; t=1,2, \ldots, T)
\end{gathered}
$$

Once the firm decides to conduct $R \& D$, the next decision point is the $R \& D$ expenditure (RDexp), i.e. how much the firm will spend on its $\mathrm{R} \& \mathrm{D}$ activities

$$
\begin{gathered}
R D \exp _{i t}=\left\{\begin{array}{c}
\beta_{1} R D \exp _{i, t-1}+\beta_{2} X_{i t}+c_{i 2}+\varepsilon_{i t 2} \text { if } R D_{i t}=1 \\
0 \quad \text { if } R D_{i t}=0
\end{array}\right. \\
(i=1,2, \ldots, n ; t=1,2, \ldots, T)
\end{gathered}
$$

Equation (1) models the long-run decision of firm $i$ to invest in R\&D activities as a latent function of its past innovation decision $\left(R D_{i, t-1}\right)$, strictly exogenous explanatory variables $\left(W_{i t}\right)$, time-invariant unobserved individual effects $\left(c_{i 1}\right)$, and an idiosyncratic error term $\left(\varepsilon_{i t 1}\right) \cdot \pi_{i t}^{*}$ is a latent variable reflecting firm's unobservable expected profit such that firm $i$ decides to innovate 
if it is above zero. Equation (2) models the short-run decision of innovator $i$ (conditional on $\left.R D_{i t}=1\right)$ as a function of its past R\&D investments $\left(R D \exp _{i, t-1}\right)$, its exogenous characteristics $\left(X_{i t}\right)$, time-invariant unobserved individual effects $\left(c_{i 2}\right)$, and an idiosyncratic error term $\left(\varepsilon_{i t 2}\right)$ independent of $X_{i t}$.

To estimate such a model, two problems have to be solved: (i) the presence of unobserved individual effects; (ii) the correlation between initial conditions and the individual effects. Researchers increasingly apply the Wooldridge (2005) method as a solution for the initial values problem in dynamic random-effects panel data models (Raymond et al., 2010). However, in comparison with the alternative Heckman (1981)'s reduced-form approximation, the Wooldridge method does not specify an explicit conditional probability distribution for the initial values, and produces significant bias for short panels (Akay, 2012).

Heckman (1981) develops an approximation method for the conditional distribution of the initial values using a reduced-form equation:

$$
\begin{gathered}
\pi_{i 1}^{*}=\theta w_{i 1}+\varepsilon_{i 1}(3) \\
\varepsilon_{i 1}=\theta_{1} c_{i}+u_{i 1}
\end{gathered}
$$

where $\pi_{i 1}^{*}$ is the initial values of the process; $w_{i 1}$ is the vector of available first observations of strictly exogenous instruments; $\theta$ and $\theta_{1}$ are the parameters to be estimated; $\varepsilon_{i 1}$ is the composite error, in which $\varepsilon_{i 1}$ is correlated with $c_{i}$, but uncorrelated with $u_{i 1}$ for $t>1$. The reduced form can be expressed for probit model as $R D_{i 1}=1\left(\pi_{i 1}^{*}>0\right)$. Simultaneous estimation of the parameters of the structural equation (1-2) and reduced-form in (4-5) can be obtained by the maximization of the likelihood function when the conditional distribution of initial values is known.

However, it is our assumption that the propensity of firms' engagement in R\&D activities is due to external factors, such as industry structure, internal absorptive capacity, entrepreneurial motivation, etc., rather than the self-selection effect. Thus, we will apply two-tiered (or doublehurdle) dynamic Tobit type-2 model. Cragg (1971) proposed a two-tiered model to allow the parameters which characterize the participation decision $\left(R D_{i t}=0\right.$ or $\left.R D_{i t}=1\right)$ to be separate from the parameters which determine the expenditure decision (how much $R D \exp _{i t}$ is) given that $R D_{i t}=1$. The Cragg model might be a better choice than Heckman's sample selection model since it is more appropriate for characterizing the dataset by treating $R D \exp _{i t}$ (given $R D_{i t}=0$ ) observed and being equal to zero rather than as unobserved in Heckman model. 
Following Chang (2011), we apply the corrected random effects approach for the two-tiered dynamic panel Tobit models. Let consider unobserved individual heterogeneity $c_{i}$, follows Wooldridge (2002):

$$
c_{i}=\gamma_{0}+\gamma \bar{x}_{i}+d_{i} ; \quad \bar{x}_{i}=\frac{1}{T} \sum_{t=1}^{T} x_{i t}
$$

Equation (6) will be used to model unobserved individual heterogeneity in the estimation of equations (1) and (2). The Cragg model integrates the probit model to determine the probability of $R D \exp _{i t}>0$ and the truncated normal model for given positive values of $R D \exp _{i t}$.

Estimation of a sample selection model generally requires an "exclusion restriction". Hu et al. (2005) show that proper industry variables could become effective instruments to correct for firm specific effects. These variables define the environment in which the firms operate and yet are independent of a firm's specific characteristics. Thus, we use industry average profitability and industry average firm size as the exclusion restrictions, assuming that industry-level characteristics will be more likely to influence firms' propensity to innovate or engage in R\&D rather than determining their own innovation effort. The exclusion restriction test proposed by Das et al. (2003) indeed shows that the two variables are good exclusion at 5\% significant level.

\subsection{Performance equation}

We consider both static and dynamic estimation models for the third stage of firms' innovation process, i.e. outcome of $\mathrm{R} \& \mathrm{D} /$ innovation investment. In the dynamic model, lagged dependent variable is included to isolate the effect of potential performance shock as well as to account for necessary time lag until the pay-off of R\&D investment can be recognized. The firm profitability equation can be written as follows:

$$
\begin{aligned}
& \operatorname{ROS}_{i t}=\operatorname{ROS}_{i t-1} \delta_{1}+\operatorname{RDint}_{i t} \delta_{2}+\text { INNinvest }_{i t} \delta_{3}+z_{i t} \delta_{4}+v_{i}+\epsilon_{i t} \\
& (i=1,2, \ldots, n ; t=1,2, \ldots, T)
\end{aligned}
$$

In equation (8) above, $R O S_{i t-1}$ is the 1-year lagged value of return on sales of firm $i$ in year $t$. RDint $_{i t}$ is the R\&D intensity of firm $i$, INNinvest $_{i t}$ is the rate innovation investment of firm $i, z_{i t}$ is a matrix of control firm-level, province-level and industry-level characteristics. $v_{i}$ an unobserved firm-specific time-invariant effect which allows for heterogeneity in the means of the $R O S_{i t}$ series across firms, and $\epsilon_{i t}$ is a disturbance term. A key assumption maintained throughout this work is that the disturbances $\epsilon_{i t}$ are independent across individuals. We also treat the firm- 
effects $v_{i}$ as stochastic, which implies that they are necessarily correlated with lagged dependent variable $R O S_{i t-1}$.

Test for violations of estimation assumptions: $E\left(\epsilon_{i t} \epsilon_{i^{\prime} t^{\prime}}\right)=\left\{\begin{array}{ccc}\sigma_{\epsilon}^{2} & i=i^{\prime}, t=t^{\prime} & (H 1) \\ 0 & \text { otherwise } & (H 2)\end{array}\right.$

- Heteroskedasticity (H1) : We apply the likelihood ratio test for heteroskedasticity in panel data and find out the strong existence of heteroskedasticity in our data ${ }^{4}$.

- Serial correlation in time-series data (H2): The Wooldridge test for first-order autocorrelation in panel data is insignificant even at the $10 \%$ level, which indicates the absence of first-order serial correlation in the ROS equation ${ }^{5}$.

- Endogeneity of R\&D intensity and innovation investment rate: The Durbin-Wu-Hausman test does indicate the strong presence of the endogeneity for innovation investment rate, but does not show the problem of endogeneity for R\&D intensity ${ }^{6}$.

Given the test results above, we apply the instrumental variable generalized method of moments (GMM) approach for estimation of the static model (cluster by firms). We use the industry entry rate (proxied for industry dynamics) as the IV here, assuming that the dynamics or turbulence of the industry influence significantly firms' innovative efforts, i.e. how much they will invest in $R \& D$, but play an insignificant role in determining firm-level profitability which is more likely a function of firm-level variables. For dynamic model, we use the Arellano-Bond (1991) difference GMM estimator. The lagged levels of endogenous regressor INNinvest $t_{i t}$ are used as instruments, which rise over time in both models. This makes the endogenous variable pre-determined and thus not correlated with the error term in equation (1).

By transforming the regressors by first differencing, the fixed firm-specific effect is removed, because it does not vary with time:

$\Delta R O I_{i t}=\beta_{1} \Delta R O S_{i t-1}+\beta_{2} \Delta I N N$ invest $_{i t}+\beta_{3} \Delta z_{i t}+\Delta \epsilon_{i t}$

\footnotetext{
${ }^{4}$ White/Koenker nR2 test statistic: $\chi^{2}(81)=327.967$; $\mathrm{p}$-value $=0.000$.

${ }^{5}$ Wooldridge first-order serial correlation test: $\mathrm{F}(1,11006)=1.079$; $\mathrm{p}$-value $=0.299$

${ }^{6} \mathrm{H}_{0}$ : "Innovation investment rate" is exogenous

Durbin-Wu-Hausman $\chi^{2}$ test $\quad \chi^{2}(1)=10.639 \quad$ P-value $\quad=0.001$

$\mathrm{H}_{0}$ : " $\mathrm{R} \& \mathrm{D}$ intensity" is exogenous

Durbin-Wu-Hausman $\chi^{2}$ test $\quad \chi^{2}(1)=0.013 \quad$ P-value $=0.907$
} 


\section{Estimation results and Discussion}

\section{$5.1 R \& D$ equation}

If we compare estimation results across two methodological treatments, sign and statistical significance of estimated parameters are quite consistent although the magnitude seems to be larger with coefficients from Heckman (1981)'s approach (Table 2). Both methods accept the null hypothesis that the lagged dependent variables in the selection and the main equation are significantly different from zero, meaning that the experience of conducting R\&D activities is persistent overtime. Past experience influences firms’ decisions at present and in future.

We analyze first findings from the selection equation. Significant and positive parameters of debt ratio indicate the leverage effect of loans on stimulating firms' R\&D activities. Obviously, firms endowed with prior technological resources (a large pool of skilled technical employees) and achieving some successful innovation outputs (registered innovations) are more likely involved in $R \& D$ than their counterparts. In turn, exporting firms are more likely to undertake $\mathrm{R} \& \mathrm{D}$ in order to capture emerging demands, advanced technology and resources from international markets. Finally, it is crucial for diversified firms to invest in R\&D activities when extending their portfolio of products to capitalize knowledge spillovers in new business sectors.

With respect to the effects of size and age on the likelihood of firms being innovative, we find statistically significant and non-linear positive effect of both labor size and economic size on firms’ R\&D involvement: firms are more likely to undertake $R \& D$ as they get bigger up to a point, beyond which their motivation for R\&D starts to fade away. Younger firms are significantly more innovative than their older counterparts. Finally, we witness the positive relationship between industry profitability, proxied by average industry ROS, and firms' R\&D participation decision. Apparently, firms residing in growing industry will conduct more $R \& D$, either bringing more innovative products or applying new technologies to enhance productivity, in order to exploit emerging profitable opportunities available within their own industry.

Once firms decide to undertake $R \& D$, which factors will determine their $R \& D$ expenditure? We again observe the consistency in the general pattern of results obtained. It is worth noting that the effects of some variables, for instance technological resources, innovation output, export, and debt ratio in this equation contradict with their equivalent effects in the above R\&D decision equation, which indicates that factors stimulating firms to engage in $R \& D$ do not necessarily influence their R\&D spending to the same extent and vice versa. 
- Table 1 about here -

First, as expected, although a large reservoir of technical employees stimulates firms to engage in $R \& D$, there is a tradeoff between $R \& D$ expenditure and payroll cost for technical personnel. Firms obviously have to incur higher operating cost for maintaining this technical team. Similarly, although firms with some prior innovation output achievements are more likely to conduct R\&D activities, they do not necessarily invest more on $R \& D$ compared to their counterparts. Second, exporting firms are more likely to be innovative to exploit abundant entrepreneurial opportunities that they realize from doing business transactions with foreign business partners; but there is no evidence that they will spend more on R\&D. Third, multibusiness firms are generally more $R \& D$ intensive than single-business firms. Fourth, highly leveraged firms, despite being more innovative, desire to capitalize short-term and liquidated profitable opportunities to compensate for incurring the burden of high capital cost, rather than pursuing luxurious $R \& D$ activities that are generally costly and time-consuming. Fifth, larger firms are more R\&D intensive than their small counterparts. Firms possessing larger asset pool have more favourable conditions to invest in $R \& D$, and hence, are more incentivised to bring up radical innovations. However, firms spend more on R\&D as they get bigger up to a point, but start to spend less marginally when their size go beyond this point. Sixth, consistent with findings from other advanced countries, we also find statistical evidences to prove that young firms are more R\&D intensive and innovative than their older peers (Veugelers, 2008).

\subsection{Performance equation}

Statistical evidences in table 3 show that, consistent with our hypothesis H3, private innovative firms significantly outperform their peers. The economic effect is much stronger when we take into account the performance of all three types of firms together in treatment (3). YICs and SY firms also achieve superior performance, but the effect is not statistically significant. Hypothesis $\mathrm{H} 2$ is not supported. Thus, the combination of smallness, newness and innovativeness fails to fulfill the profit expectation for YICs' innovative efforts in Vietnam.

We find statistically significant positive effect of innovation inputs ( $R \& D$ intensity, innovation investment rate, and technical personnel rate) on firm-level profitability. Hypothesis 
H1 is supported. However, the significant and negative quadratic term of innovation investment rate indicates a non-linear relationship between investment into innovation activities and firm performance: profit increases as innovation investment is exploited up to the optimal point, but starts to fall off marginally when investment goes beyond this optimal point. This tends to limit the firm's innovation output to the extent that owners-managers should achieve optimum investment efficiency. Both capital intensive and highly leveraged firms are found to be less profitable. Although there is broad agreement on the benefits of debt, it may be argued that large firms are more likely to receive more benefits than SMEs at the same level of debt ratio. Since 92\% of the sample of our firms is SMEs, the debt burden indeed imposes a serious impediment to firm value. The increasing contribution of foreign investment in the total legal registered investment also does not help to boost up firms' entrepreneurial profitability. This finding is somewhat consistent with the recent decreasing ranking of Vietnam business environment in attracting foreign investments due to many institutional constraints, including complex administrative regulation, excessive bureaucracy and frequent changes in requirements (Thanh, 2005). Finally, we also find statistical evidences for the outperformance of firms operating in multi-business sectors and/or exporting their products/services into international markets.

Contradictory results are found between economic and labor size. Firms possessing larger asset pool are normally capital intensive, and thus incur higher sunk cost and transaction costs due to their "asset specificity", which impedes their profit margins. This finding is also consistent with the negative effect of capital intensity on firms' profitability. However, larger firms in terms of labor size are found to have superior performance compared to their smaller counterparts. As expected, firms residing in growing industries with substantial profit opportunities obtain positive spillover effects from the industry to stimulate their growth.

\section{- Table 2 about here -}

\section{Controlling for potential survival bias}

This section takes into account the potential survival bias during and after engaging in R\&D activities (Table 3). If innovative firms are less likely to survive and hence exit the market easily compared to other firms, we would overestimate the economic value of innovation as our sample only accounts for firms that were established before 2000 and still survive until 2005. 


\section{- Table 3 about here -}

Our data cover the whole population of firms in Vietnam, so non-random data collection is not a cause of concern. Any firm failing to appear in the next-year survey can be assumed to have gone bankrupt or have been acquired by other firms. In this section, we aim to address: (i) whether firms engaging in R\&D activities are more likely to exit the market, and (ii) whether surviving firms have higher profit margin than other firms, which is consistent with the finding above. We apply the standard Heckman selection model to control for firm survival with the firm population as obtained from the annual GSO's enterprise survey from 2000 to 2005. The database contains nearly 400,000 observations that could be used for the survival analysis. In the first stage, we estimate the probability of firm survival using probit model (survival stage). The Heckman's inverse Mills ratio computed from the first stage will be included in the second stage to estimate the profitability of surviving firms (performance stage). As above, we use average ROS and average firm size of the industry as the exclusion restriction in the Heckman selection model. Table 3 presents the estimation results of both stages.

The insignificant Mills ratio indicates the absence of survival bias in our estimation model even at $10 \%$ significant level. Thus, we can feel confident that our estimation results above with the extracted 6-year panel sample do not overestimate the economic value of firms' R\&D activities. The first-stage survival equation produces some note-worthy findings: first, R\&D and innovation investment not only stimulate firm growth and profitability significantly (as discussed above) but also are critical for firm survival. Firms engaging in R\&D activities are less likely to exit the market than other firms. A higher rate of technical personnel over the whole labor force also helps firms to prevent the risk of going bankrupt. Second, both highly leveraged firms and exporting firms have higher propensity of survival than their counterparts; whereas foreigninvested firms expose a higher failure rate. Third, we found statistical evidences to support the positive relationship between size and age of firms and their survival probability. For decades, incumbent large (state-owned) firms have always played a crucial role in leading technological progress and economic performance in transition countries although their dominant market position starts to be gradually taken place by emerging private counterparts recently. And finally, obviously, firms residing in growing industries (high average ROS) have plenty of 
entrepreneurial opportunities to exploit, and thus are more likely to survive than those residing in mature industries which are dominated by large-size firms.

\section{Conclusion and policy implications}

This paper has investigated the determinants of $R \& D$ engagement and $R \& D$ intensity, the economic value of innovation and R\&D activities in Vietnam, a fast-growing transition country. We controlled for selectivity and endogeneity issue of the innovation process in three consecutive stages. Particularly, Cragg's two-tiered dynamic type-2 Tobit model and Heckman’s approximation for initial conditions method were adopted in the first two stages: factors determining the probability of firms' participating in R\&D activities and their R\&D expenditure after participation. Then the instrumental variable GMM and differenced GMM method were applied for both static and dynamic treatment of the third performance stage. In this stage, we also tested whether young innovative firms, private innovative firms, small and young firms outperform their counterparts.

The estimation results support our two hypotheses on the important role of R\&D and innovation activities in sustaining firms' survival and stimulating their profitability; and private innovative firms significantly outperform their peers. However, it is crucial to take into account that the factors motivating firms to be involved in $R \& D$ do not necessarily induce them to invest more in R\&D. For instance, loans have a leverage effect on $R \& D$ engagement decision, but demotivate innovative firms to spend more on R\&D. Highly leveraged firms and capital intensive firms are found to be less profitable as well. In the same fashion, there is a tradeoff between R\&D expenditure and payroll cost for technical personnel. A large pool of skilled technical employees on one hand stimulates firms to conduct R\&D activities, but on the other hand deters firms' R\&D investment due to high operating cost that they need to incur in order to maintain this technical team. Similarly, although firms with some prior innovation output achievements are more likely to conduct $R \& D$ activities, they do not necessarily invest more on their R\&D compared to their counterparts, and thus do not exhibit any higher profit margin or sales growth. Firms exporting their products/services into international markets are more likely to be innovative to exploit abundant entrepreneurial opportunities that they realize from doing business transactions with foreign business partners; but there is no evidence suggesting that they will spend more on R\&D. Other worth-noting findings include: multi-business firms are 
generally more $R \& D$ intensive and perform better than single-business firms do. We found contradictory effect between labor size and economic size. Firms being endowed with larger asset pool have more favorable conditions to engage in innovation activities, but do not necessarily produce superior performance relatively to their smaller counterparts. However, firm labor size is positively associated with both R\&D intensity and entrepreneurial performance of firms. In terms of age effect, although younger firms are more R\&D intensive and innovative, they do not produce equivalent outperformance. Therefore, the combination of young, small, and innovative characteristics in YICs does not bring the expected higher entrepreneurial performance as how it works in advanced countries.

Given significant barriers impeding YICs to conduct their own R\&D investment and innovation activities, the typical next step in the argumentation is a need for policies to address these barriers. First, to stimulate the contribution of SMEs to innovation, SME innovation policy needs to create a favorable environment for innovation (Veugelers, 2008). Although the number of wholly state-owned firms has decreased as a result of the ongoing 'equitization' process in Vietnam, the SOE sector with its established oligopoly market power still dominates the technological market by controlling complimentary assets of appropriating returns from innovation. Thus, political stability, institutional reform, and an open and transparent market should be the priority and prerequisite for policy makers. Second, SME innovation policy needs differentiation. Small firms face different barriers and are stimulated by different factors compared to their large counterparts during the R\&D and innovation process. Third, potential innovators would never have the incentive to spend on R\&D, knowing that returns to innovation will quickly disappear, and that they will then be out-competed by free-riders enjoying lower costs. Thus, a lack of an efficient and formal appropriation system is another challenge that impedes firms in transition countries to engage in risky and costly $R \& D$ investment. IPRs, specifically the patent system, not only provide incentives, but also set opportunities and constraints for the directions of technological advances and market testing. 
Table 1: Participation and investment in R\&D activities

\begin{tabular}{|c|c|c|}
\hline Variables & $\begin{array}{l}\text { Heckman's sample selection } \\
\text { (initial con. approximation) }\end{array}$ & $\begin{array}{l}\text { Cragg's two-tiered } \\
\text { dynamic Tobit model }\end{array}$ \\
\hline \multicolumn{3}{|c|}{ Selection equation: Probability of engaging in $R \& D$ activities } \\
\hline R\&D engagement, $t-1$ & $14.492 * *(0.272)$ & $7.159 * *(0.358)$ \\
\hline Technical personnel rate & $1.005 * *(0.135)$ & $0.637 * *(0.173)$ \\
\hline Innovation output (patents) & $0.065 *(0.028)$ & $0.063 *(0.026)$ \\
\hline Capital intensity & $-0.0005(0.003)$ & $-0.0004(0.0003)$ \\
\hline Export & $0.606 *(0.249)$ & $0.083(0.064)$ \\
\hline Diversification & $0.187 * *(0.041)$ & $0.163 * *(0.054)$ \\
\hline Labor size & $0.3003 * *(0.039)$ & $0.211 * *(0.043)$ \\
\hline Labor size squared & $-0.019 * *(0.005)$ & $-0.018 * *(0.0049)$ \\
\hline Economic size & $0.186 * *(0.051)$ & $0.228 * *(0.057)$ \\
\hline Economic size squared & $-0.009 * *(0.0029)$ & $-0.011 * *(0.003)$ \\
\hline Debt ratio & $0.275^{* *}(0.042)$ & $0.749 * * *(0.066)$ \\
\hline Firm age & $-1.029 * *(0.052)$ & $-1.077 * *(0.053)$ \\
\hline Foreign investment & $-0.262(0.421)$ & $1.398(0.783)$ \\
\hline Industry ROS & $1.3001^{* *}(0.296)$ & $1.681 * *(0.309)$ \\
\hline Industry average firm size & $0.00003(0.00008)$ & 0.00003 (0.00009) \\
\hline Joint sig. of ownership type dummies & $\chi^{2}(5)=50.93^{* *}$ & \\
\hline Joint sig. of initial conditions & $\chi^{2}(8)=529.66^{* *}$ & \\
\hline \multicolumn{3}{|l|}{ Joint sig. of group means } \\
\hline Intercept & $-1.669 * *(0.205)$ & $-4.925 * *(0.232)$ \\
\hline \multicolumn{3}{|l|}{ Main equation: R\&D expenditure } \\
\hline R\&D expenditure, $t-1$ & $0.491 * *(0.0086)$ & $0.409 * *(0.0084)$ \\
\hline Technical personnel rate & $-0.659 * *(0.076)$ & $-0.753 * *(0.081)$ \\
\hline Innovation output (patents) & $-0.0043 *(0.0017)$ & $-0.0046 * *(0.0017)$ \\
\hline Capital intensity & $0.0003(0.0007)$ & $0.0003(0.0006)$ \\
\hline Export & $-0.091 * *(0.034)$ & $-0.132 * *(0.027)$ \\
\hline Diversification & $0.111 *(0.047)$ & $0.193 * *(0.049)$ \\
\hline Labor size & $0.186 * *(0.062)$ & $0.042(0.0704)$ \\
\hline Labor size squared & $-0.003(0.007)$ & $-0.0033(0.007)$ \\
\hline Economic size & $0.523 * *(0.085)$ & $0.281 * *(0.098)$ \\
\hline Economic size squared & $-0.011 * *(0.004)$ & $-0.0054(0.0051)$ \\
\hline Debt ratio & $-0.145^{*}(0.065)$ & $-0.0049(0.074)$ \\
\hline Firm age & $-0.49 * *(0.0103)$ & $-0.526 * *(0.011)$ \\
\hline Foreign investment & $-0.044(0.405)$ & $-0.882(0.883)$ \\
\hline Industry ROS & & $-0.558(0.495)$ \\
\hline Industry average firm size & & $-0.00005(0.0001)$ \\
\hline Joint sig. of ownership type dummies & $\chi^{2}(5)=242^{* *}$ & \\
\hline Joint sig. of initial conditions & $\chi^{2}(8)=2177^{* *}$ & \\
\hline Intercept & $0.096(0.338)$ & $-0.635(0.381)$ \\
\hline Wald test & $\chi^{2}(26)=12555^{* *}$ & $\chi^{2}(28)=1870.43^{* *}$ \\
\hline Wald test $($ rho $=0)$ & $\chi^{2}(1)=1719 * *$ & \\
\hline No. of observations & 55035 & 55035 \\
\hline
\end{tabular}

Note: The estimation of both models uses standard errors clustered by firms

Standard errors are in parentheses

*: significant at $5 \%$ level; **: significant at $1 \%$ level 
Table 2: Performance of YICs, PICs, and SYs

\begin{tabular}{|c|c|c|c|c|c|c|}
\hline \multirow{3}{*}{ Variables } & \multicolumn{6}{|c|}{ Return on sales (ROS) } \\
\hline & \multicolumn{3}{|c|}{ Static GMM model } & \multicolumn{3}{|c|}{ Dynamic GMM model } \\
\hline & (1) & (2) & (3) & (4) & (5) & (6) \\
\hline ROS, t-1 & & & & $\begin{array}{l}0.031 \\
(0.026)\end{array}$ & $\begin{array}{l}0.031 \\
(0.026)\end{array}$ & $\begin{array}{l}0.031 \\
(0.026)\end{array}$ \\
\hline YIC & $\begin{array}{l}0.0063 \\
(0.0082)\end{array}$ & & $\begin{array}{l}0.0129 \\
(0.0083)\end{array}$ & $\begin{array}{l}0.038 \\
(0.054)\end{array}$ & & $\begin{array}{l}0.036 \\
(0.057)\end{array}$ \\
\hline PIC & & $\begin{array}{l}0.007^{*} \\
(0.0037)\end{array}$ & $\begin{array}{l}0.0108^{* *} \\
(0.0045)\end{array}$ & & $\begin{array}{l}0.023 * * \\
(0.009)\end{array}$ & $\begin{array}{l}0.021 \\
(0.013)\end{array}$ \\
\hline SY & & & $\begin{array}{l}0.0051 \\
(0.0035)\end{array}$ & & & $\begin{array}{l}-0.004 \\
(0.013)\end{array}$ \\
\hline R\&D intensity & $\begin{array}{l}0.109 * * \\
(0.017)\end{array}$ & $\begin{array}{l}0.111 * * \\
(0.018)\end{array}$ & $\begin{array}{l}0.104^{* *} \\
(0.018)\end{array}$ & $\begin{array}{l}0.105 \\
(0.067)\end{array}$ & $\begin{array}{l}0.103 \\
(0.067)\end{array}$ & $\begin{array}{l}0.105 \\
(0.067)\end{array}$ \\
\hline Innovation investment & $\begin{array}{l}0.135 * * \\
(0.028)\end{array}$ & $\begin{array}{l}0.135^{* *} \\
(0.028)\end{array}$ & $\begin{array}{l}0.134^{* *} \\
(0.028)\end{array}$ & $\begin{array}{l}1.25 * * \\
(0.324)\end{array}$ & $\begin{array}{l}1.33 * * \\
(0.336)\end{array}$ & $\begin{array}{l}1.332 * * \\
(0.337)\end{array}$ \\
\hline Innovation investment squared & $\begin{array}{l}-0.277 * * \\
(0.055)\end{array}$ & $\begin{array}{l}-0.276^{* *} \\
(0.055)\end{array}$ & $\begin{array}{l}-0.276 * * \\
(0.055)\end{array}$ & $\begin{array}{l}-1.63^{* *} \\
(0.407)\end{array}$ & $\begin{array}{l}-1.731 * * \\
(0.423)\end{array}$ & $\begin{array}{l}-1.732 * * \\
(0.424)\end{array}$ \\
\hline Technical personnel & $\begin{array}{l}0.055 * * \\
(0.016)\end{array}$ & $\begin{array}{l}0.054 * * \\
(0.016)\end{array}$ & $\begin{array}{l}0.055^{* *} \\
(0.016)\end{array}$ & $\begin{array}{l}0.04 * \\
(0.017)\end{array}$ & $\begin{array}{l}0.039 * \\
(0.017)\end{array}$ & $\begin{array}{l}0.039 * \\
(0.017)\end{array}$ \\
\hline Innovation output & $\begin{array}{l}-0.00002 \\
(0.0001)\end{array}$ & $\begin{array}{l}-0.0002 \\
(0.001)\end{array}$ & $\begin{array}{l}-0.0002 \\
(0.001)\end{array}$ & $\begin{array}{l}0.00001 \\
(0.0001)\end{array}$ & $\begin{array}{l}0.00001 \\
(0.0001)\end{array}$ & $\begin{array}{l}0.00001 \\
(0.0001)\end{array}$ \\
\hline Capital intensity & $\begin{array}{l}-0.0005^{* *} \\
(0.0002)\end{array}$ & $\begin{array}{l}-0.0005^{* *} \\
(0.0002)\end{array}$ & $\begin{array}{l}-0.0005^{* *} \\
(0.0002)\end{array}$ & $\begin{array}{l}-0.00004 \\
(0.0001)\end{array}$ & $\begin{array}{l}-0.00004 \\
(0.0001)\end{array}$ & $\begin{array}{l}-0.00004 \\
(0.0001)\end{array}$ \\
\hline Export & $\begin{array}{l}0.0095 * \\
(0.005)\end{array}$ & $\begin{array}{l}0.0093^{*} \\
(0.005)\end{array}$ & $\begin{array}{l}0.0095^{*} \\
(0.005)\end{array}$ & $\begin{array}{l}0.013 \\
(0.01)\end{array}$ & $\begin{array}{l}0.012 \\
(0.01)\end{array}$ & $\begin{array}{l}0.012 \\
(0.01)\end{array}$ \\
\hline Diversification & $\begin{array}{l}0.0083^{* *} \\
(0.0025)\end{array}$ & $\begin{array}{l}0.0082^{* *} \\
(0.0025)\end{array}$ & $\begin{array}{l}0.0082 * * \\
(0.0025)\end{array}$ & $\begin{array}{l}0.002 \\
(0.004)\end{array}$ & $\begin{array}{l}0.002 \\
(0.004)\end{array}$ & $\begin{array}{l}0.002 \\
(0.004)\end{array}$ \\
\hline Debt ratio & $\begin{array}{l}-0.024^{* *} \\
(0.0067)\end{array}$ & $\begin{array}{l}-0.024^{* *} \\
(0.0067)\end{array}$ & $\begin{array}{l}-0.024^{* *} \\
(0.0067)\end{array}$ & $\begin{array}{l}-0.029 * * \\
(0.011)\end{array}$ & $\begin{array}{l}-0.03^{* *} \\
(0.011)\end{array}$ & $\begin{array}{l}-0.03^{* *} \\
(0.011)\end{array}$ \\
\hline Labor size & $\begin{array}{l}0.0132 * * \\
(0.005)\end{array}$ & $\begin{array}{l}0.0131^{* *} \\
(0.005)\end{array}$ & $\begin{array}{l}0.0128^{* *} \\
(0.005)\end{array}$ & $\begin{array}{l}0.0002 \\
(0.016)\end{array}$ & $\begin{array}{l}0.0002 \\
(0.016)\end{array}$ & $\begin{array}{l}0.0002 \\
(0.016)\end{array}$ \\
\hline Labor size squared & $\begin{array}{l}-0.0018^{* *} \\
(0.0006)\end{array}$ & $\begin{array}{l}-0.0018 * * \\
(0.0006)\end{array}$ & $\begin{array}{l}-0.0018^{* *} \\
(0.0006)\end{array}$ & $\begin{array}{l}-0.0007 \\
(0.0019)\end{array}$ & $\begin{array}{l}-0.0007 \\
(0.0019)\end{array}$ & $\begin{array}{l}-0.0007 \\
(0.0019)\end{array}$ \\
\hline Economicsize & $\begin{array}{l}-0.0515^{* *} \\
(0.0068)\end{array}$ & $\begin{array}{l}-0.0515^{* *} \\
(0.0068)\end{array}$ & $\begin{array}{l}-0.051 * * \\
(0.0068)\end{array}$ & $\begin{array}{l}-0.022 \\
(0.017)\end{array}$ & $\begin{array}{l}-0.024 \\
(0.017)\end{array}$ & $\begin{array}{l}-0.024 \\
(0.017)\end{array}$ \\
\hline Economic size squared & $\begin{array}{l}0.0035^{* *} \\
(0.0004)\end{array}$ & $\begin{array}{l}0.003 * * \\
(0.0004)\end{array}$ & $\begin{array}{l}0.0035^{* *} \\
(0.0004)\end{array}$ & $\begin{array}{l}0.001 \\
(0.0009)\end{array}$ & $\begin{array}{l}0.001 \\
(0.0009)\end{array}$ & $\begin{array}{l}0.001 \\
(0.0009)\end{array}$ \\
\hline Firmage & $\begin{array}{l}-0.0001 \\
(0.0001)\end{array}$ & $\begin{array}{l}-0.0001 \\
(0.0001)\end{array}$ & $\begin{array}{l}-0.00001 \\
(0.0001)\end{array}$ & $\begin{array}{l}0.006^{* *} \\
(0.0022)\end{array}$ & $\begin{array}{l}0.006 * * \\
(0.0023)\end{array}$ & $\begin{array}{l}0.006 * * \\
(0.0023)\end{array}$ \\
\hline Foreign investment & $\begin{array}{l}-0.198 * * \\
(0.038)\end{array}$ & $\begin{array}{l}-0.197 * * \\
(0.038)\end{array}$ & $\begin{array}{l}-0.198 * * \\
(0.038)\end{array}$ & $\begin{array}{l}-0.093 \\
(0.136)\end{array}$ & $\begin{array}{l}-0.089 \\
(0.137)\end{array}$ & $\begin{array}{l}-0.089 \\
(0.137)\end{array}$ \\
\hline Industry ROS & $\begin{array}{l}0.223^{* *} \\
(0.092)\end{array}$ & $\begin{array}{l}0.224^{* *} \\
(0.092)\end{array}$ & $\begin{array}{l}0.222^{* *} \\
(0.091)\end{array}$ & $\begin{array}{l}0.069 \\
(0.108)\end{array}$ & $\begin{array}{l}0.069 \\
(0.108)\end{array}$ & $\begin{array}{l}0.07 \\
(0.108)\end{array}$ \\
\hline Average firm size & $\begin{array}{l}-0.0002 \\
(0.0002)\end{array}$ & $\begin{array}{l}-0.0002 \\
(0.0002)\end{array}$ & $\begin{array}{l}-0.0002 \\
(0.0002)\end{array}$ & $\begin{array}{l}0.00006 \\
(0.0002)\end{array}$ & $\begin{array}{l}0.00005 \\
(0.0002)\end{array}$ & $\begin{array}{l}0.00005 \\
(0.0002)\end{array}$ \\
\hline Ownership type dummies & $\begin{array}{l}\mathrm{F}(5,11006) \\
=67.12^{* *}\end{array}$ & $\begin{array}{l}\mathrm{F}(5,11006) \\
=67.65^{* *}\end{array}$ & $\begin{array}{l}\chi^{2}(5)= \\
67.51 * *\end{array}$ & $\begin{array}{l}\chi^{2}(5)= \\
15.62^{* *}\end{array}$ & $\begin{array}{l}\chi^{2}(5)= \\
15.32 * *\end{array}$ & $\begin{array}{l}\chi^{2}(5)= \\
15.38 * *\end{array}$ \\
\hline Province dummies & $\begin{array}{l}\chi^{2}(60)= \\
840.03^{* *}\end{array}$ & $\begin{array}{l}\chi^{2}(60)= \\
840.69 * *\end{array}$ & $\begin{array}{l}\chi^{2}(60)= \\
842.87^{* *}\end{array}$ & & & \\
\hline Intercept & $\begin{array}{l}0.166^{* *} \\
(0.021)\end{array}$ & $\begin{array}{l}0.167 * * \\
(0.021) \\
\end{array}$ & $\begin{array}{l}0.164^{* *} \\
(0.022) \\
\end{array}$ & $\begin{array}{l}0.036 \\
(0.064) \\
\end{array}$ & $\begin{array}{l}0.04 \\
(0.064)\end{array}$ & $\begin{array}{l}0.044 \\
(0.065) \\
\end{array}$ \\
\hline F-value & $\begin{array}{l}\mathrm{F}(86,54950) \\
=28.61^{* *}\end{array}$ & $\begin{array}{l}\mathrm{F}(86,54950) \\
=28.62^{*}\end{array}$ & $\begin{array}{l}\mathrm{F}(86,54950) \\
=28.57 * *\end{array}$ & & & \\
\hline Wald statistic & & & & $\begin{array}{l}\chi^{2}(24)= \\
83.79 * *\end{array}$ & $\begin{array}{l}\chi^{2}(24)= \\
92.80^{* *}\end{array}$ & $\begin{array}{l}\chi^{2}(26)= \\
94.69 * *\end{array}$ \\
\hline Hansen J statistic of excl instr. & $\chi^{2}(1)=3.101$ & $\chi^{2}(1)=3.136$ & $\chi^{2}(1)=3.102$ & & & \\
\hline Observations & 55035 & 55035 & 55035 & 44028 & 44028 & 44028 \\
\hline
\end{tabular}

Note: *: significant at $5 \%$ level; **: significant at $1 \%$ level

Standard errors are used in both methodological treatments to adjust for clustering on firm code 
Table 3: Controlling for survival bias

\begin{tabular}{lll}
\hline \hline Variables & $\begin{array}{c}\text { First stage: } \\
\text { Probability of survival }\end{array}$ & $\begin{array}{c}\text { Second stage: } \\
\text { Profitability of survivors }\end{array}$ \\
\hline R\&D intensity & $0.453^{* *}(0.038)$ & $0.167^{* *}(0.011)$ \\
Innovation investment & $1.832^{* *}(0.0376)$ & $0.076^{* *}(0.014)$ \\
Innovation investment squared & $-1.997^{* *}(0.039)$ & $-0.171^{* *}(0.014)$ \\
Technical personnel rate & $0.121^{* *}(0.012)$ & $0.071^{* *}(0.0035)$ \\
Innovation output (patents) & $-0.002^{* *}(0.0007)$ & $0.0005(0.0003)$ \\
Capital intensity & $-0.00009(0.0001)$ & $-0.00003(0.00003)$ \\
Debt ratio & $0.0027^{* *}(0.0005)$ & $-0.0004^{* *}(0.0001)$ \\
Export & $0.612^{* *}(0.0102)$ & $0.0097^{*}(0.0045)$ \\
Foreign investment & $-0.0003^{*}(0.00017)$ & $0.00008(0.0006)$ \\
Diversification & $0.0083(0.0102)$ & $0.017^{* *}(0.0029)$ \\
Labor size & $0.084^{* *}(0.0066)$ & $0.0012(0.0018)$ \\
Labor size squared & $-0.009^{* *}(0.001)$ & $-0.0005^{*}(0.0003)$ \\
Economic size & $0.129^{* *}(0.0085)$ & $-0.0039^{*}(0.0023)$ \\
Economic size squared & $-0.0038^{* *}(0.0005)$ & $0.0006^{* *}(0.0002)$ \\
Firm age & $0.035^{* *}(0.0005)$ & $-0.0002(0.0002)$ \\
Industry ROS & $2.36^{* *}(0.038)$ & \\
Industry average firm size & $-0.0004^{*}(0.0002)$ & $\chi^{2}(5)=2137^{* *}$ \\
Joint sig. of ownership type dummies & $\chi^{2}(5)=4127^{* *}$ & $\chi^{2}(66)=2323^{* *}$ \\
Joint sig. of province dummies & $\chi^{2}(66)=4645^{* *}$ & $0.0036(0.0057)$ \\
Mills ratio & & $0.018^{*}(0.0084)$ \\
Intercept & $0.558^{* *}(0.032)$ & $13207^{* *}$ \\
\hline Wald test & & 418435 \\
No. of observations & & \\
\hline \hline
\end{tabular}

Note: *: significant at 5\% level; **: significant at 1\% level 
Appendix 1: Descriptive statistics of available variables

\begin{tabular}{|c|c|c|c|c|c|c|c|}
\hline Indicators & Variables & Measure & Obs. & Mean & Std. Dev. & Min & Max \\
\hline Accounting measures & ROS: Return on sales & ROS $=\frac{\text { Operatingprofit }}{\text { Totalsales }}$ & 66042 & 0.0083 & 0.356 & -17.75 & 13.54 \\
\hline \multirow{3}{*}{ Types of firms } & Young innovative firms (YIC) & $Y I C_{i t}=\left\{\begin{array}{c}1 \text { ifage }_{i t}<6 \& \text { labor }_{i t}<250 \& R \& D_{i t}>15 \% \\
0 \text { otherwise }\end{array}\right.$ & 66042 & 0.0219 & 0.146 & 0 & 1 \\
\hline & Private innovative firms & $P I C_{i t}=\left\{\begin{array}{c}1 \text { ifownership }_{i t}=\text { privatefirms } \& R \& D_{i t}>0 \\
0 \text { otherwiseorifYIC } C_{i t}=1\end{array}\right.$ & 66042 & 0.067 & 0.2501 & 0 & 1 \\
\hline & Small and youngfirms & 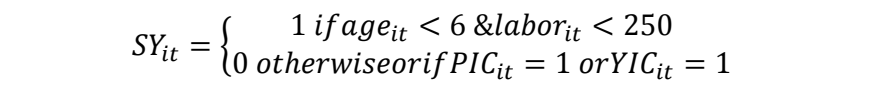 & 66042 & 0.563 & 0.4959 & 0 & 1 \\
\hline \multirow{5}{*}{ Innovation } & R\&D expenditure & Natural of logarithm of R\&D spending / expenditure & 66042 & 1.081 & 2.394 & 0 & 12.231 \\
\hline & R\&D intensity & The ratio between R\&D expenditure and total production expenses & 66042 & 0.022 & 0.098 & 0 & 0.994 \\
\hline & Innovation investment rate & $\begin{array}{l}\text { The ratio between investment into innovation activities and total } \\
\text { annual business investment }\end{array}$ & 66042 & 0.075 & 0.166 & 0 & 1 \\
\hline & Technical human resources & The rate of technical personnel in total firm labor force & 66042 & 0.057 & 0.163 & 0 & 1 \\
\hline & Innovation output & Number of innovation projects/patents firm has achieved & 66042 & 0.126 & 4.436 & 0 & 632 \\
\hline \multirow{2}{*}{ Firmsize } & Laborsize & Natural logarithm of the number of total employees & 66042 & 3.009 & 1.682 & 0 & 9.171 \\
\hline & Economicsize & Natural logarithm of total assets & 66042 & 7.807 & 2.045 & 0 & 16.494 \\
\hline Firmage & Firmage & Number of years firm has been operating & 66042 & 9.386 & 8.126 & 0 & 105 \\
\hline Firm export & Export & The dummy attains 1 if the firm exports, 0 otherwise & 66042 & 0.115 & 0.319 & 0 & 1 \\
\hline Firm diversification & Diversification & The dummy attains 1 if the firm diversifies, 0 otherwise & 66042 & 0.146 & 0.353 & 0 & 1 \\
\hline Financial leverage & Debt ratio & Debtratio $=\frac{\text { Totaldebt }}{\text { Totalassets }}$ & 66042 & 0.346 & 0.324 & 0 & 1 \\
\hline Capital intensiveness & Capital intensity & Capitalintensity $=\frac{\text { Fixedassets }}{\text { Numberofemployees }}$ & 66042 & 102.37 & 628.95 & 0 & 74367 \\
\hline Foreigninvestment & Foreigninvestment rate & The rate of foreign investment in the total annual investment & 66042 & 0.058 & 0.223 & 0 & 1 \\
\hline \multirow{4}{*}{ Control variables } & Ownershiptypes & \multirow{2}{*}{\multicolumn{6}{|c|}{$\begin{array}{l}\text { Dummy variables for } 6 \text { ownership types: (1) State-owned firms; (2) Cooperatives and Partnership; (3) Private firms; (4) Limitec } \\
\text { liability firms; (5) Joint stock firms; (6) Foreign-invested firms } \\
\text { Dummy variables for } 64 \text { provinces of Vietnam }\end{array}$}} \\
\hline & Province & & & & & & \\
\hline & Industry: averagefirmsize & $\begin{array}{l}\text { The ratio between total employees in the industry and the number of } \\
\text { firms in the industry }\end{array}$ & 66042 & 71.753 & 120.86 & 9.64 & 3387.03 \\
\hline & $\begin{array}{l}\text { Industry: average industry } \\
\text { ROS }\end{array}$ & $\frac{1}{n} \sum_{i}^{n} \frac{\text { operatingprofit }_{i}}{\text { Totalsales }_{i}} \quad$ (n firms in the industry) & 66042 & 0.022 & 0.043 & -0.281 & 0.411 \\
\hline
\end{tabular}


Appendix 2: Pairwise correlation matrix for available variables

\begin{tabular}{|c|c|c|c|c|c|c|c|c|c|c|c|c|c|c|}
\hline & ROS & $\begin{array}{l}\mathrm{R} \& \mathrm{D} \\
\text { intensit }\end{array}$ & $\begin{array}{l}\text { Innov. } \\
\text { Invest }\end{array}$ & $\begin{array}{l}\text { Tech.p } \\
\text { erso }\end{array}$ & $\begin{array}{l}\text { Innov. } \\
\text { Output }\end{array}$ & $\begin{array}{l}\text { Capital } \\
\text { intensit }\end{array}$ & Export & $\begin{array}{l}\text { Labor } \\
\text { size }\end{array}$ & $\begin{array}{l}\text { Eco. } \\
\text { Size }\end{array}$ & $\begin{array}{l}\text { Debt } \\
\text { ratio }\end{array}$ & Firm age & $\begin{array}{l}\text { Fore. } \\
\text { Invest }\end{array}$ & $\begin{array}{l}\text { Indus } \\
\text { try } \\
\text { ROS }\end{array}$ & $\begin{array}{l}\text { Average } \\
\text { firmsize }\end{array}$ \\
\hline ROS & 1.000 & & & & & & & & & & & & & \\
\hline $\begin{array}{l}\mathrm{R} \& \mathrm{D} \\
\text { intensity }\end{array}$ & $.032 *$ & 1.000 & & & & & & & & & & & & \\
\hline $\begin{array}{l}\text { Innovation } \\
\text { invest. }\end{array}$ & $-.022 *$ & $.117^{*}$ & 1.0000 & & & & & & & & & & & \\
\hline $\begin{array}{l}\text { Technical } \\
\text { personnel }\end{array}$ & -.004 & $-.021^{*}$ & $-.011^{*}$ & 1.000 & & & & & & & & & & \\
\hline $\begin{array}{l}\text { Innovation } \\
\text { output }\end{array}$ & .0031 & .002 & .0016 & $.018 *$ & 1.0000 & & & & & & & & & \\
\hline $\begin{array}{l}\text { Capital } \\
\text { intensity }\end{array}$ & $-.075^{*}$ & $.018^{*}$ & .0005 & $.065^{*}$ & -.0006 & 1.0000 & & & & & & & & \\
\hline Export & $-.012 *$ & $.022 *$ & $.019 *$ & .0025 & $.015 *$ & $.011^{*}$ & 1.0000 & & & & & & & \\
\hline Laborsize & $-.013^{*}$ & $.068 *$ & $.08^{*}$ & $.042 *$ & $.064^{*}$ & $.038 *$ & $.311^{*}$ & 1.0000 & & & & & & \\
\hline $\begin{array}{l}\text { Economics } \\
\text { ize }\end{array}$ & $-.029 *$ & $.062 *$ & $.051 *$ & $.108 *$ & $.056 *$ & $.206^{*}$ & $.276^{*}$ & $.783 *$ & 1.0000 & & & & & \\
\hline Debt ratio & $-.027 *$ & $.021 *$ & $.031 *$ & $.116^{*}$ & $.022 *$ & $.051 *$ & $.153^{*}$ & $.445 *$ & $.555 *$ & 1.0000 & & & & \\
\hline Firmage & .0039 & $.027 *$ & $-.019 *$ & -.0075 & $.024 *$ & .0009 & $.043^{*}$ & $.147^{*}$ & $.157 *$ & $.103^{*}$ & 1.0000 & & & \\
\hline $\begin{array}{l}\text { Foreigninv } \\
\text { estment }\end{array}$ & $-.053^{*}$ & $.012 *$ & $.022 *$ & $.049 *$ & .0023 & $.131 *$ & $.221 *$ & $.252 *$ & $.296^{*}$ & $.083^{*}$ & $.024 *$ & 1.0000 & & \\
\hline $\begin{array}{l}\text { Industry } \\
\text { ROS }\end{array}$ & $.032 *$ & $.045 *$ & $.025 *$ & $.045 *$ & $.011^{*}$ & $.054 *$ & .0072 & $.153 *$ & $.134 *$ & $.096 *$ & $.043 *$ & $.065 *$ & 1.000 & \\
\hline $\begin{array}{l}\text { Averagefir } \\
\text { msize }\end{array}$ & $-.025^{*}$ & $.049 *$ & $.039 *$ & $-.013^{*}$ & $.041 *$ & .0078 & $.192 *$ & $.375^{*}$ & $.22 *$ & $.108^{*}$ & $.011 *$ & $.178 *$ & $.107^{*}$ & 1.0000 \\
\hline
\end{tabular}

Note: *:significantat $1 \%$ level 


\section{References}

Acs Z. J. and Audretsch D. B. (1990). Innovation and Small Firms. Boston: MIT Press.

Acs Z. J. and Audretsch D. B. (1998). Innovation in Large and Small Firms: An Empirical Analysis. American Economic Review, 78(4): 678-690.

Acz Z. , Braunerhjelm P. , Audretsch D. B. and Carlsson B. (2009). The Knowledge Spill-over Theory of Entrepreneurship, Small Business Economics, 32(1): 15-30.

Akay A. (2012). Finite-sample comparison of alternative methods for estimating dynamic panel data models, Journal of Applied Econometrics, 27(7): 1189-1204.

Anton J. and Yao D. (1994). Expropriation and Inventions: Appropriable Rents in the Absence of Property Rights. American Economic Review, 84(1): 190-209.

Arellano M. and Bond S. (1991). Some Tests of Specification for Panel Data: Monte Carlo Evidence and An Application to Employment Equations. Review of Economic Studies, 58 (2): 277-297.

Artes J. (2009). Long-run versus Short-run Decisions, R\&D and Market Structure in Spanish Firms. Research Policy, 38(1): 120-132.

Audretsch D. B. , Thurik A. R. , Verheul I. and Wennekers A. R. M. (eds). (2002). Entrepreneurship: Determinants and Policy in a European-US Comparison. Boston, MA and Dordrecht, The Netherlands: Kluwer Academic Publishers.

Audretsch D. B. (1995). Innovation, Growth and Survival. International Journal of Industrial Organization, 13(4): 441-457.

Audretsch D. B. (2006). Entrepreneurship, Innovation, and Economic Growth. Chaltham: Edward Elgar Publishing.

Autio E. , Kronlund M. and Kovalainen A. (2007). High-Growth SME Support Initiatives in Nine Countries: Analysis, Categorisation, and Recommendations. Report prepared for the Finnish Ministry of Trade and Industry. MTI Publications 1/2007.

Baumol W. J. , Litan R. E. , and Schramm C. J. (2007). Good Capitalism, Bad Capitalism. New Haven: Yale University Press.

Birley S. and Westhead P. (1990). Growth and Performance Contrasts Between Types of Small Firms. Strategic Management Journal, 11(7): 535-557.

Blundell R. , Griffith R. , and Van Reenen J. (1999). Market Share, Market Value and Innovation in A Panel of British Manufacturing Firms. Review of Economic Studies, 66(3): 529-554.

Canto J. G. D. and Gonzalez I. S. (1999). A Resource-Based Analysis of the Factors Determining A Firm's R\&D Activities. Research Policy, 28 (8): 891-905.

Carree M. A. and Thurik A. R. (2010). The Impact of Entrepreneurship on Economic Growth. In Acs Z. J. and Audretsch D. B. (eds). Handbook of Entrepreneurship Research, Vol. 5 of International Handbook Series on Entrepreneurship. Springer: New York.

Carree M. , Della Malva A. , and Santarelli, E. , (2013). The Contribution of Universities to Growth: Empirical Evidence for Italy. Forthcoming in Journal of Technology Transfer, Doi: 10. 1007/s10961-012-9282-7

Castellani D. (2002). Export Behavior and Productivity Growth: Evidence from Italian Manufacturing Firms. Weltwirtschaftliches Archiv, 138(4): 605-628.

Cefis E. and Marsili O. (2006). Survivor: the Role of Innovation in Firms' Survival. Research Policy, 35 (5): 626 641.

Chang S. K. (2011). Simulation Estimation of Two-Tiered Dynamic Panel Tobit Models with An Application to the Labor Supply of Married Women. Journal of Applied Econometrics, 26 (5): 854-871.

Chuang Y. and Lin C. (1999). Foreign Direct Investment, R\&D and Spillover Efficiency: Evidence from Taiwan's Manufacturing Firms. The Journal of Development Studies, 35(4): 117-137.

Clerides S. K. , Lach S. , and Tybout J. R. (1998). Is Learning by Exporting Important? Micro-dynamic Evidence from Colombia, Mexico and Morocco. Quarterly Journal of Economics, 113(3): 903-947.

Cohen W. M. and Levin R. C. (1989). Empirical Studies of Innovation and Market Structure. In Schmalensee R. and Willig R. D. (eds). Handbook of Industrial Organization, Vol. II, pp. 1060-1098. Amsterdam: North-Holland.

Cohen W. M. and Levinthal D. (1990). Absorptive Capacity: A New Perspective on Learning and Innovation. Administrative Science Quarterly, 35(1): 128-152. 
Cohen W. (1995). Empirical Studies of Innovative Activity. Chapter 6 in Stoneman P. (eds). Handbook of the Economics of Innovation and Technological Change. Blackwell Publishers: Oxford.

Cooper R. G. (1984). New Product Strategies: What Distinguishes the top performers?. Journal of Product Innovation Management, 1 (3): 151-164.

Cragg J. G. (1971). Some Statistical Models for Limited Dependent Variables with Application to the Demand for Durable Goods. Econometrica, 39 (5): 829-844.

Criscuolo P. , Nicolaou N. , and Salter A. (2012). The Elixir (or Burden). of Youth? Exploring Differences in Innovation between Start-ups and Established Firms. Research Policy, 41(2): 319-333.

Czarnitki D. and Kraft K. (2004). Management Control and Innovative Activity. Review of Industrial Organization, 24(1): 1-24.

Czarnitzki D. and Delanote J. (2013). Young Innovative Companies: the New High-Growth Firms? Industrial and Corporate Change, 22(5): 1315-1340.

Damijan J. P. , Knell M. , Majcen B. and Rojec M. (2003). Technology Transfer through FDI in Top-10 Transition Countries: How Important are Direct Effects, Horizontal and Vertical Spillovers?, William Davidson Institute Working Papers Series 549, William Davidson Institute.

Das M. , Newey W. K. and Vella F. (2003). Nonparametric Estimation of Sample Selection Models. Review of Economic Studies, 70(1): 33-58.

DeCarolis D. M. and Deeds D. (1999). The Impact of Stocks and Flows of Organizational Knowledge on Firm Performance: An Empirical Investigation of the Biotechnology Industry. Strategic Management Journal, 20 (10): 953-968.

Dosi G. , Marengo L. , and Pasquali C. (2007). Knowledge, Competition and Innovation: Is Strong IPR Protection Really Needed for More and Better Innovations?. Michigan Telecommunications and Technology Law Review, 13: 471-485.

Dosi G. (1988). Sources, Procedures and Microeconomic Effects of Innovation. Journal of Economic Literature, 26(3): 1120-1171.

Downs G. W. and Mohr L. B. (1976). Conceptual Issues in the Study of Innovation. Administrative Science Quarterly, 21 (4): 700-714.

Freel M. (2000). Do Small Innovating Firms Outperform Non-innovators?. Small Business Economics, 14(3): 195210

Freeman C. (1994). Innovation and Growth. In Dodgson M. And Rothwell R. (eds). The Handbook of Industrial Innovation. Cheltenham: Edward Elgar.

Fritsch M. , Brixy U. , and Falck O. (2006). The Effect of Industry, Region, and Time on New Business Survival A Multi-Dimensional Analysis. Review of Industrial Organization, 28(3): 285-306.

Gans J. S. , Hsu D. H. and Stern S. (2002). When Does Start-up Innovation Spur the Gale of Creative Destruction?. RAND Journal of Economics, 33 (4): 571-586.

Geringer J. M. , Beamish P. W. and daCosta R. C. (1989). Diversification Strategy and Internationalization: Implications for MNE Performance. Strategic Management Journal, 10(2): 109-119.

Geroski P. and Machin S. (1992). Do Innovating Firms outperform Non-innovators?. Business Strategy Review, 3(1): 79-90.

Gibrat R. (1931). Les Inegalites Economiques. Librairie du Recueil Sirey: Paris.

Guo R. , Lev B. and Chi S. (2006). Explaining the Short- and Long-Term IPO Anomalies in the US by R\&D. Journal of Business Finance \& Accounting, 33 (3-4): 550-579.

Heckman J. J. (1981). The Incidental Parameters Problem and the Problem of Initial Conditions in Estimating A Discrete Time Discrete Data Stochastic Process, in Manski C. And McFadden D. (eds). The Structural Analysis of Discrete Data and Econometric Applications. Boston: MIT Press.

Henderson R. (1993). Underinvestment and Incompetence as Responses to Radical Innovation: Evidence from the Photolithographic Industry. Rand Journal of Economics, 24(2): 248-270.

Heunks F. (1998). Innovation, Creativity and Success. Small Business Economics, 10 (3): 263-272.

Hölzl W. (2009). Is the R\&D Behaviour of Fast Growing SMEs Different? Evidence from CIS III Data for 16 Countries. Small Business Economics, 33(1): 59-75.

Hu A. G. Z, Jefferson G. H. and Jinchang Q. (2005). R\&D and Technology Transfer: Firm Level Evidence from Chinese industry. Review of Economics and Statistics, 87 (4): 780-786. .

Kim. L. and Nelson R. R. (2000). Technology, Learning and, Innovation: Experiences of Newly Industrializing Economies. Cambridge: Cambridge University Press.

Kleinknecht A. (1987). Measuring R\&D in Small Frms: How Much Are We Missing?. Journal of Industrial Economics, 36 (2). 253-256. 
Klepper S. (1996). Entry, Exit, Growth, and Innovation over the Product Cycle. American Economic Review, 86(3): 562-583.

Krammer S.M.S. (2009). Drivers of national innovation in transition: Evidence from a panel of Eastern European countries. Research Policy, 38(5): 845-860.

Krugman P. R. (1979). A Model for Innovation, Technology, Transfer and the World Distribution of Income. Journal of Political Economy, 87 (2): 253-263.

Kumar N. and Saqib M. (1996). Firm Size, Opportunities for Adaptation and In-house R\&D Activity in Developing Countries: the Case of Indian Manufacturing. Research Policy, 25 (5): 713-722.

Levinthal D. A. and March J. G. (1993). The Myopia of Learning. Strategic Management Journal, 14(1): 95-112

Licht G. and Nerlinger E. (1998). New Technology-based Firms in Germany: A Survey of the Recent Evidence. Research Policy, 26(9): 1005-1022.

Lotti F. , Santarelli E. , and Vivarelli M. (2003). Does Gibrat's Law Hold among Young, Small Firms?. Journal of Evolutionary Economics, 13(3): 213-235.

Lotti F. , Santarelli E. And Vivarelli M. (2009). Defending Gibrat's Law As a Long-run Regularity. Small Business Economics, 32 (1): 31-44.

Miller D. and Friesen P. (1984). A Longitudinal Study of the Corporate Life Cycle. Management Science, 30 (10): 1161-1183.

Moore B. (1995). What Differentiates Innovative Small Firms?. Innovation Initiative Paper No. 4, ESRC Centre for Business Research, University of Cambridge.

Nelson R. and Winter S. (1982). An Evolutionary Theory of Economic Change. Belknap Press: Cambridge, MA.

North D. and Smallbone D. (1995). Employment Generation and Small Business Growth, in Different Geographical Environment. In Chittenden F., Robertson M. , and Marshall I. (eds). Small Firms: Partnerships for Growth. Paul Chapman: London, pp 100-115.

Opler T. C. and Titman S. (1994). Financial Distress and Corporate Performance. Journal of Finance, 49(3): 10151040.

Piva M. and Vivarelli M. (2009). The Role of Skills As a Major Driver of Corporate R\&D. International Journal of Manpower, 30(8): 835-852.

Raymond W., Mohnen R., Palm F., and Schim van der Loeff S. (2010). Persistence of Innovation in Dutch Manufacturing: Is it Spurious?. Review of Economics and Statistics, 92(3): 495-504.

Romero I. and Román M. J. A. (2012). Self-employment and Innovation. Exploring the Determinants of Innovative Behavior in Small Businesses. Research Policy, 41(1). 178-189.

Rosenbusch N. , Brinckmann J. and Bausch A. (2011). Is Innovation Always Beneficial? A Meta-analysis of the Relationship between Innovation and Performance in SMEs. Journal of Business Venturing, 26(4): 441-457.

Rothwell R. (1974). Innovation in Textile Machinery: Some Significant Factors in Success and Failure, Science Policy Research Unit: University of Sussex.

Santarelli E. and Sterlacchini A. (1990). Innovation, Formal vs. Informal R\&D, and Firm Size: Some Evidence from Italian Manufacturing Firms. Small Business Economics, 2(3): 223-228.

Santarelli E. and Tran H. T. (2012). Growth of Incumbent Firms and Entrepreneurship in Vietnam. Growth and Change, 43 (4): 638-666.

Santarelli E. and Tran H. T. (2013). The Interplay of Human Capital and Social Capital in Shaping Entrepreneurial Performance: The Case of Vietnam. Small Business Economics, 40 (2): 435-458.

Schmookler J. (1996). Invention and Economic Growth. Cambridge Harvard University Press

Schneider C. and Veugelers R. (2008). On Young Innovative Companies: Why They Matter and how (not) to Policy to Support Them. Working Paper No. 04/2008. Department of Economics, Copenhagen Business School.

Schumpeter J. A. (1934). The Theory of Economic Development. Cambridge: Harvard University Press.

Schumpeter J. A. (1942). Capitalism, Socialism and Democracy. New York: Harper and Row.

Song J. , Almeida P. and Wu G. (2003). Learning-by-hiring: When Is Mobility More Likely to Facilitate Interfirm Knowledge Rransfer?. Management Science, 49(4): 351-365.

Souitaris V. (2002). Firm-Specific Competencies Determining Technological Innovation: A Survey in Greece. $R \& D$ Management, 32(1): 61-77.

Thanh V. T. (2005). Vietnam's Trade Liberalization and International Economic Integration: Evolution, Problems and Challenges. ASEAN Economic Bulletin, 22(1): 75-91.

Tran H. T. and Santarelli E. (2013). Capital Constraints and the Performance of Entrepreneurial Firms in Vietnam. Forthcoming in Industrial and Corporate Change, DOI:10. 1093/icc/dtt030

Vaona A. and Pianta M. (2008). Firm Size and Innovation in European Manufacturing. Small Business Economics, 30(3): 283-299. 
Vermeulen P. A. M. , de Jong J. P. J. and O’Shaughnessy K. C. (2005). Identifying Key Determinants for New Product Introductions and Firm Performance in Service SMEs. The Service Industries Journal, 25(5): 625-640.

Veugelers R. (1997). Internal R\&D Expenditures and External Technology Sourcing. Research Policy, 26(3): 303315.

Veugelers R. (2008). The Role of SMEs in Innovation in the EU: A Case for Policy Intervention?. Review of Business Economics, 53(3): 239-262.

Wooldridge J. M. (2002). Econometric Analysis of Cross Section and Panel Data. Cambridge, Massachusetts: MIT Press.

Wooldridge J. M. (2005). Simple Solutions to the Initial Conditions Problem in Dynamic, Nonlinear Panel Data Models with Unobserved Heterogeneity. Journal of Applied Econometrics, 20(1): 39-54. 


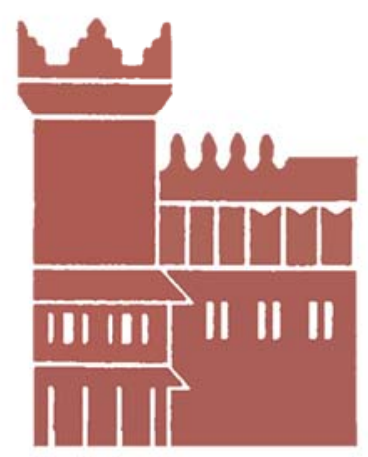

Alma Mater Studiorum - Università di Bologna DEPARTMENT OF ECONOMICS

Strada Maggiore 45

40125 Bologna - Italy

Tel. +39051 2092604

Fax +390512092664

http://www.dse.unibo.it 